копитающих // Известия ТСХА. - 2012. - Вып. 2. C. $58-65$.

3. Календарь Р.Н., Глазко В.И. Типы молекулярногенетических маркеров и их применение // Физиология и биохимия культурных растений. - 2002. T. 34. - № 4. - С. 279-296.

4. Полилокусное генотипирование крупного рогатого скота по участкам гомологии к ретротранспозонам / В.И. Глазко [и др.] // Сельскохозяйственная биология. - 2015. - Т. 50. - № 6. - С. 766-775.

5. Zietkiewicz E., Rafalski A., Labuda D. (1994). Genome fingerprinting by seguence repeat (SSR) anchored polymerase chain reaction amplification // Genomics, Vol. 20, P. 176-183.

Егорова Ксения Ивановна, аспирант, Научноисследовательский институт пушного звероводства и кролиководства имени В.А. Афанасъева. Россия.

140143, Московская обл., Раменский р-н, n.2.т. Родники, ул. Трудовая, 6.

Тел.: (495) 744-26-42.
Глазко Валерий Иванович, $\partial-p$ c.- $x$. наук, проф. кафедры «Зоология», Российский государственный аграрный университет - МСХА им. К.А. Тимирязева. Россия.

127550, г. Москва, ул. Тимирязевская, 49.

Тел.: (499) 977-14-55.

Шумилина Анна Рудольфовн $а$, канд. биол. наук, Научно-исследовательский институт пушного звероводства и кролиководства имени В.А. Афанасьева. Россия.

Косовский Глеб Юрьевич, $\partial$-р биол. наук, проф. РАН, Научно-исследовательский институт пушного звероводства и кролиководства имени В.А. Афанасьева. Россия.

140143, Московская обл., Раменский p-н, n.2.m. Родники, ул. Трудовая, 6.

Тел.: (495) 744-26-42.

Ключевые слова: ISSR-маркеры; доля полиморфных локусов; полиморфное информационное содержание; кролик; трехпородный кросс.

\title{
GENETIC STRUCTURE OF THREE-WAY CROSS OF RABBITS IN COMPARISON WITH PARENTAL BREEDS
}

Egorova Ksenia Ivanovna, Post-graduate Student, Scientific Research Institute of Fur Farming and Rabbit Breeding Industries. Russia.

Glazko Valeriy Ivanovich, Doctor of Agricultural Sciences, Professor, Russian State Agrarian University - Moscow Timiryazev Agricultural Academy (RSAU - MTAA or RSAU - MAA named after K.A. Timiryazev), Russia.

Shumilina Anna Rudolfovna, Candidate of Biological Sciences, Scientific Research Institute of Fur Farming and Rabbit Breeding Industries, Russia.

Kosovkiy Gleb Yurevich, Doctor of Biological Sciences, Professor of RAS, Scientific Research Institute of Fur Farming and Rabbit Breeding Industries, Russia.

Keywords: ISSR-markers; the share of polymorphic loci; polymorphic information content; rabbit; three-way cross.
The comparative analysis of polymorphism of DNA fragments, flanking by the inverted repeats of microsatellites (ISSR-PCR markers) in three-way cross of rabbits and three parental breeds of rabbits was carried out. 26 loci are revealed by using three trinucleotide ISSR-markers $\left((\mathrm{GAG})_{6} \mathrm{C},(\mathrm{ACC})_{6} \mathrm{G} u(\mathrm{CTC})_{6} \mathrm{C}\right), 20$ of them being polymorphous. The most changeable there were the spectra of amplification products of primer (CTC) ${ }_{6} C$. Relative increased consolidation of three-way cross of rabbits in comparison with parental breeds such as White Giant, Soviet Chinchilla and Californian rabbits as also unique characteristics of their genetic structure in comparisons with parental breeds have been found.

\section{ВИРИНЕЯ - НОВЫЙ АДАПТИВНЫЙ СОРТ ЛЮЦЕРНЫ в ПОВОЛЖЬЕ}

\author{
ПОПОВА Татьяна Николаевна, ФГБНУ «Ершовская ОСОЗ НИИСХ Юго-Востока» \\ НАЙДОВИЧ Владимир Александрович, ФГБНУ «Ершовская ОСОЗ НИИСХ Юго-Востока» \\ КУЗНЕЦОВ Павел Александрович, ФГБНУ «Ершовская ОСОЗ НИИСХ Юго-Востока»
}

\begin{abstract}
На Ершовской опытной станиии работа по селекции ведется с 1976 2., создано 8 новых сортов люцерны. Последний из них под названием Виринея передан на Государственное сортоиспытание в 2016 2. Основные достоинства сорта: адаптивность, высокая продуктивность, устойчивость к болезням. В среднем за пять лет урожайность зеленой массы составила 13,6 m/га, семян-387,7 к2/га, у сорта-стандарта Узенъ соответственно 10,5 m/га и 309,4 к2/га. Уровенъ рентабельности сорта Виринея по этим показателям выше на 21,4 и 77 \% соответственно по сравнению со стандартом.
\end{abstract}

Введение. Люцерна (лат. Medicágo) относится к семейству Бобовые (Fabaceae) $[1,4]$. Это не только ценнейшее кормовое растение, люцерна применяется в медицине, а в ряде стран используется также в пищу [8]. В России наибольшее распространение она получила в XX веке [3]. В Саратовской облас- ти, в основном в правобережных районах, ее стали выращивать с конца XIX века [5].

Люцерна - ценный предшественник, так как не только обогащает почву органической массой и азотом, но и улучшает ее структуру. Способность к высокой кормовой урожайнос- 
ти выдвинула люцерну в ряд главных бобовых многолетних растений во многих странах, в том числе в России, в частности в Поволжье. На орошаемых землях Заволжья она является главной многолетней бобовой культурой [2].

Цель данной работы - показать биологические и экономические особенности нового сорта люцерны Виринея.

Методика исследований. Ершовская опытная станция относится к зоне рискованного земледелия. Климатические условия характеризуются резкими колебаниями температуры воздуха, количества и времени выпадения осадков, летом к тому же - сухостью воздуха и сильными ветрами. Почвы - темно-каштановые тяжелосуглинистые, содержание гумуса 3,0-3,8 \%.

Исследовали новый сорт люцерны - Виринея селекции Ершовской ОСОЗ. В конкурсном сортоиспытании на семенную продуктивность ежегодно высевали 10-15 номеров. Делянки двухрядковые длиной 19 м высевали весной сеялкой ССФК-7 широкорядно, с междурядьем 70 см, в четырехкратной повторности, норма высева семян 3 кг на 1 га. Площадь делянок $25 \mathrm{~m}^{2}$. На семена убирали во второй год жизни, с первого укоса [7].

Проводили фенологические наблюдения, высоту растений замеряли перед цветением и в конце цветения, учитывали тип окраски венчика и форму куста в цветение, поражение растений болезнями и вредителями. Снопы, отобранные с площади $1 \mathrm{~m}^{2}$ каждой повторности, подвергали структурному анализу, учитывали массу, длину снопа, количество продуктивных и непродуктивных стеблей, узлов, кистей, семян в бобе, бобов в кисти и массу семян. Убирали делянки комбайном Сампо 130. Урожайность рассчитывали, исходя из учетной площади делянки и массы семян с делянки [6].

Питомник конкурсного сортоиспытания на кормовую продуктивность высевали сплошным способом с междурядьем 15 см в шестикратной повторности. На площади делянки 13 м² высевали ежегодно 10-15 номеров. Учитывали густоту стояния, высоту травостоя весной и перед каждым укосом. Активность отрастания определяли через 7-10 дней после каждого укоса; оценку на общую мощность и устойчивость к возбудителям заболе- ваний проводили перед каждым укосом. Отбирали килограммовые снопы перед каждым укосом, в двух повторениях, определяли выход сухого вещества. В лабораторных условиях определяли выход воздушно-сухого вещества, абсолютно сухую массу, массу стеблей и листьев. За вегетационный период проводили от двух до пяти укосов комбайном E-300.

Результаты исследований. На Ершовской опытной станции с 1976 г. ведется работа по селекции люцерны, основным направлением которой является выведение сортов с повышенной семенной и кормовой продуктивностью, устойчивостью к болезням. Из популяции № 2/08, выведенной на Ершовской ОСОЗ путем отборов из гибридной комбинации от скрещивания сорта Жидруне (к-38914 Литва mv) и дикорастущей люцерны Актюбинская (к-39085 mv), получен сорт люцерны синей Виринея.

Вид - люцерна синяя Medicago sativa. Pacтения среднерослые. Форма куста полупрямостоячая. Окраска листьев светло-зеленая. Окраска венчика фиолетовая, сиреневая. Соцветие - кисть длинно-цилиндрическая и головчатая. Листья средней величины. Популяция среднеспелая.

Урожайность зеленой массы составила в среднем за пять лет 13,6 т/га, семян - 387,7 кг/га, а у сорта-стандарта Узень - 10,5 т/га и 309,4 кг/га. Соответственно в процентном соотношении прибавка урожая нового сорта к стандарту составила: зеленой массы - $30 \%$, семян - $25 \%$ (табл. 1).

Анализ полученных данных показал, что в процессе селекции идет постоянное улучшение показателей. Так, если урожай первого созданного на станции сорта Ерусланка (год допуска 1993) принять за $100 \%$, то сорт Узень (2006 г.) по урожаю зеленой массы на уровне этого сорта, а по семенам урожайнее на $10 \%$. Сорт Виринея, переданный на Государственное испытание в 2016 г., соответственно на 39 и $38 \%$.

Наибольшую устойчивость к корневым гнилям на искусственном инфекционном фоне в 2013 г. показал сорт Виринея. Поражение составило 0,8 балла, по девятибалльной шкале (табл. 2). Оценку по пораженности аскохитозом проводили визуально в конкурсном сортоиспытании. Пора-

Таблица 1

Урожайность зеленой массы и семян сортов люцерны в КСИ

\begin{tabular}{|c|c|c|c|c|c|c|c|c|c|c|c|c|}
\hline \multirow{2}{*}{ Сорт } & \multicolumn{5}{|c|}{ Урожайность зеленой массы (по годам), т/га } & \multirow{2}{*}{ Среднее } & \multicolumn{5}{|c|}{ Урожайность семян (по годам), кг/га } & \multirow{2}{*}{ Среднее } \\
\hline & 2011 & 2013 & 2014 & 2015 & 2016 & & 2011 & 2013 & 2014 & 2015 & 2016 & \\
\hline Ерусланка & 7,8 & 8,5 & 14,5 & 6,1 & 11,9 & 9,8 & 393,0 & 178,8 & 396,0 & 150,0 & 288,8 & 281,3 \\
\hline Узень (st) & 9,8 & 7,6 & 13,8 & 8,2 & 13,1 & 10,5 & 476,0 & 251,3 & 399,2 & 174,4 & 246,3 & 309,4 \\
\hline Виринея & 14,7 & 9,9 & 18,4 & 9,4 & 15,4 & 13,6 & 651,0 & 215,3 & 330,0 & 250,2 & 492,0 & 387,7 \\
\hline Среднее & & & & & & 11,3 & & & & & & 326,1 \\
\hline$F_{\text {факт }}$ & & & & & & $14,1^{*}$ & & & & & & 2,4 \\
\hline $\mathrm{HCP}_{05}$ & & & & & & 1,8 & & & & & & NS \\
\hline
\end{tabular}


жение этого сорта равнялось в 2013 г. 1,7 балла, т.е. было науровне стандарта, в 2014 г. - 1,6 балла, при пораженности стандарта 1,4 балла. Поражаемость микоплазмозом и повреждение вредителями у сорта Виринея и сорта-стандарта Узень были близки по значению.

Популяция вполне конкурентоспособна, поскольку превосходит районированные сорта по урожаю корма и семян. Расчет экономических показателей возделывания люцерны сортов Узень и Виринея для получения семян и зеленой массы приведен в табл. 3.

Заключение. Проведенные нами исследования показали преимущества нового сорта Виринея. Основное достоинство нового сорта - адаптивность и высокая общая и семенная продуктивность.

Себестоимость продукции сорта Виринея по семенам ниже на

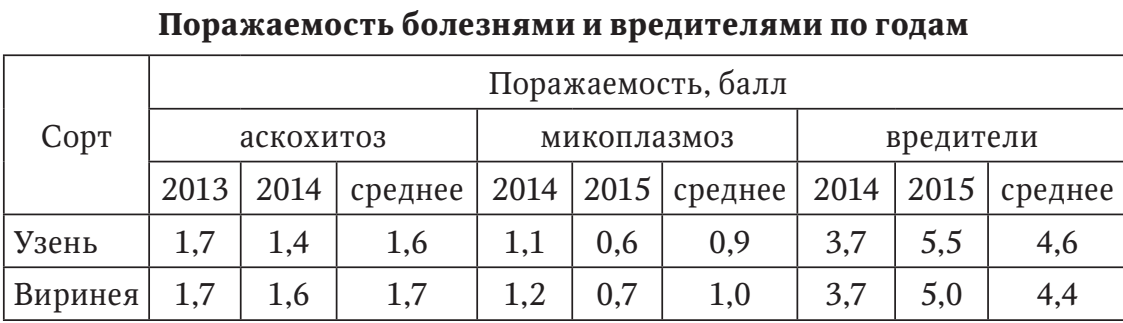

Таблица 3

Экономическая эффективность возделывания сортов люцерны

\begin{tabular}{|l|c|c|c|c|}
\hline \multirow{2}{*}{\multicolumn{2}{|c|}{ Показатель }} & \multicolumn{4}{|c|}{ Урожайность сорта } \\
\cline { 2 - 5 } & \multicolumn{2}{|c|}{ Узень (st) } & \multicolumn{2}{|c|}{ Виринея } \\
\cline { 2 - 5 } & $\begin{array}{c}\text { семян, } \\
\text { т/га }\end{array}$ & $\begin{array}{c}\text { зеленой } \\
\text { массы, т/га }\end{array}$ & $\begin{array}{c}\text { семян, } \\
\text { т/га }\end{array}$ & $\begin{array}{c}\text { зеленой } \\
\text { массы, т/га }\end{array}$ \\
\hline Урожайность основной культуры, т/га & 0,27 & 14,4 & 0,36 & 17,0 \\
\hline Цена продукции, тыс. руб./т & 200 & 1,5 & 200 & 1,5 \\
\hline Оценка продукции, тыс. руб./га & 54,0 & 21,6 & 72,0 & 25,5 \\
\hline Прямые затраты, тыс. руб./га & 23,4 & 18,2 & 23,4 & 18,2 \\
\hline Себестоимость продукции, тыс. руб./т & 86,7 & 1,3 & 65,0 & 1,1 \\
\hline Условный чистый доход, тыс. руб./га & 30,6 & 3,4 & 48,6 & 7,3 \\
\hline Уровень рентабельности, \% & 130,7 & 18,7 & 207,7 & 40,1 \\
\hline
\end{tabular}
21,7 тыс. руб./т, чем у сорта Узень, по зеленой массе почти равные показатели. Уровень рентабельности сорта Виринея выше по урожаю семян на 77 \%, по урожаю зеленой массы на 21,4 \%, чем у сорта Узень.

\section{СПИСОК ЛИТЕРАТУРЫ}

1. Гончаров П.Л., Лубенец П.А. Биологические аспекты возделывания люцерны. - Новосибирск: Наука, 1985. - 256 с.

2. Денисов Е.П., Уполовников Д.А., Шестеркин Д.Г. Перспективные кормовые культуры для черноземной зоны Поволжья // Вестник Саратовского госагроуниверситета им. Н.И. Вавилова. - 2009. - № 5. C. 30-33.

3. Константинов П.Н. Избранные сочинения. M., 1963. - 235 c.

4. Лубенеи П.А. Люцерна. - М.; Л.: Сельхозгиз, 1956. - 240 c.

5. Люцерна в Саратовской области / А.П. Царев [и др.]. - Саратов, 1985. - 88 с.

6. Малютов М.П. Селекция люцерны на семенную продуктивность в засушливом Заволжье: автореф. дис. ... канд. с.-х. наук. - Саратов, 2005. - 16 с.

7. Попова Т.Н., Найдович В.А. Взаимосвязь кормовой продуктивности с высотой растений и продолжительностью периода вегетации люцерны в засушливом Поволжье // Вавиловский журнал генетики и селекции. - 2011. - Т. 15. - № 4. - С. 794-799.

8. Duggal J., Pankaj K., Tiwari B.N. Chemo-Pharmacological Aspects of Alfalfa // Journal of Advanced Scientific Research (J.Adv.Sci.Res), 2011, No. 2(1), P. 50-53.

Попова Татьяна Николаевна, канд. с.-х. наук, научный сотрудник, ФГБНУ «Ершовская ОСОЗ НИИСХ Юго-Востока». Россия.

Найдович Владимир Александрович, канд. с.-х. наук, ведущий научный сотрудник, ФГБНУ «Ершовская ОСОЗ НИИСХ Юго-Востока». Россия.

Кузнецов Павел Александрович, зав. лабораторией селекции лющерны, ФГБНУ «Ершовская ОСОЗ НИИСХ Юго-Востока». Россия.

413502, Саратовская обл., г. Ершов, пос. Тулайково.

Тел.: 89372681541.

Ключевые слова: люцерна; сорт; уровень рентабельности; урожайность.

\section{VIRINEYA - NEW ADAPTIVE SORT OF ALFALFA IN THE VOLGA REGION}

Popova Tatyana Nikolaevna, Candidate of Agricultural Sciences, Researcher, Ershov Experimental Irrigated Farming Station, Research Agricultural Institute for South East Region. Russia.

Naydovich Vladimir Aleksandrovich, Candidate of $\mathrm{Ag}$ ricultural Sciences, Leading Researcher, Ershov Experimental Irrigated Farming Station, Research Agricultural Institute for South East Region. Russia.

Kuznetsov Pavel Aleksandrovich, Head of the laboratory of Alfalfa Selection, Ershov Experimental Irrigated Farming Station, Research Agricultural Institute for South East Region. Russia.

Keywords: alfalfa; sort; level of profitableness; yield.
On Ershov Experimental Station operation on selection is conducted about 1976 years, for these years 8 new sort of alfalfa are created. Last from them is created and transferred on a state strain testing in 2016 year under title Virineya. The basic virtues of sort: an autoadaptivity, tall productivity, resistance to sicknesses. On the average for five flying the forage yield of sort Virineya has made 13,6t/ha, a seed yield $-387,7 \mathrm{~kg} / \mathrm{ha}$, at productivity of sort - standard Uzen accordingly 10,5 t/ha and 309,4 kg/ha. Calculation of economic parameters has shown, that the level of profitableness of sort Virineya on a seed yield is higher by $77 \%$, on a total plant weight by $21,4 \%$, than at sort - standard Uzen. 